\title{
Literatura moçambicana e oralidade: uma postura crítica e uma fundamentação teórica
}

\author{
Rejane Vecchia da Rocha e Silva e Ubiratã Roberto Bueno de Souza*
}

\begin{abstract}
RESUMO
Ao utilizarmos a expressão "tradição oral africana" fazemos referência direta a uma discussão de caráter teórico que mobiliza mais questões do que respostas. O presente artigo busca, a partir de alguns trabalhos recentes da antropologia e da arqueologia africana, fazer uma revisita teórica a alguns momentos da discussão acerca da existência de uma tradição africana e de uma oralidade africana, e, em seguida, discutir a aplicabilidade desses conceitos no interior da crítica literária moçambicana a partir de uma visada diacrônica e histórica. $\mathrm{O}$ intuito é obter subsídios para uma reflexão interdisciplinar de conceitos-chave para compreensão dos diálogos interculturais que cercam a literatura moçambicana.

Palavras-chave: Tradição oral. Literatura moçambicana. Saberes endógenos. Culturas acústicas.
\end{abstract}

\section{Um percurso teórico acerca de África}

A discussão acerca da oralidade em África deve remontar, por princípio, uma questão de base, que se refere especificamente a como as ciências humanas se posicionam e se posicionaram diante das condições de produção e transmissão do conhecimento no continente africano. Há pelo menos um século que inúmeros esforços vêm sendo empreendidos para alterar definitivamente a lógica eurocêntrica, que relegava a uma parcela substancial do conhecimento africano o estatuto de não existente, baseada numa obscura justificativa de que seu suporte de produção e transmissão não era predominantemente material e visual, se tomarmos comparativamente toda a extensão do continente.

Evidentemente, essa seletividade entre conjuntos de conhecimentos que devem ser considerados ou não estava intimamente relacionada com os esforços científicos que buscavam corroborar uma visão de que espaços sociais como a África - mas também a Ásia, a Oceania e outras paragens em que o colonialismo europeu se desenvolveu - eram passíveis de colonização, uma vez que, sem cultura, esses

* Universidade de São Paulo - USP. 
povos careciam de "civilização". Os esforços para alteração dessa lógica seletiva construíram um embate científico, epistemológico e intelectual magnífico ao longo do tempo, e remontar todos os seus lugares e todas as posições que entraram no combate é um trabalho de fôlego, que precisa ser atualizado constantemente. Nesse artigo vamos remontar alguns momentos específicos desse embate, confessadamente sem a intenção de esgotá-lo, e buscar conectar essa discussão com a produção literária em língua portuguesa em Moçambique.

\section{A "África oral”}

Um dos momentos altos desse embate, e, sem dúvida, um dos mais célebres, é o texto "Tradição viva", do escritor e etnólogo malinês Amadou Hampâté-Bâ. Esse texto é construído num tom reivindicatório, e surge aos olhos do leitor atual como um manifesto em favor do reconhecimento de uma história e de uma cultura africana que se encontrava depositada naquilo que ele chama de "tradição oral". Partindo, sobretudo, de uma curta análise a respeito de como o conhecimento é transmitido e veiculado nas sociedades Bambara, situadas no Mali e em Burkina Faso, o texto de Hampâté-Bâ busca aventar hipóteses de posicionamentos diante desse repertório cultural africano que não contou com o suporte material visual até o contato com as culturas europeias, já durante o colonialismo. A preocupação principal de HampâtéBâ parece ser a de refletir a respeito das fontes orais do conhecimento a partir de sua fidedignidade, característica recusada pela ciência eurocêntrica. Seu argumento propõe justamente que as fontes orais sejam consideradas como um testemunho histórico, cujo valor e fidedignidade sejam aquelas aplicáveis a quaisquer outros testemunhos em quaisquer suportes, ou, como prefere dizer, o testemunho oral "vale o que vale o homem" (HAMPÂTÉ-BÂ, 2010, p. 168).

O contexto que subjaz à escrita de Hampâté-Bâ é justamente de certa angústia pela possibilidade de desaparecimento da cultura dos chamados "tradicionalistas" que conservavam, em seus ofícios, os repertórios culturais a que o etnólogo faz referência como "tradição oral”, justamente por conta do cenário de conflito cultural entre as culturas endógenas africanas e a hegemonia da cultura ocidental colonial. Anteriormente, pensadores mais radicais da situação colonial não hesitaram em anunciar a "morte da cultura" dos povos colonizados. Com efeito, ao verem desmoronar aos seus olhos inúmeras formas de organização social que suportavam práticas culturais muito específicas, pouquíssimas outras analogias de linguagem lhes restariam senão a figura da morte. Aimé Césaire, por exemplo, reflete: 
O mecanismo dessa morte da cultura e das civilizações sob o regime colonial começa a ser bem conhecido. Para desabrochar, toda a cultura precisa de um enquadramento, de uma estrutura. Ora, não há dúvida que os elementos que estruturam a vida cultural do povo colonizado desaparecem ou degeneram devido ao regime colonial. Trata-se, bem entendido, em primeiro lugar, da organização política. Pois é preciso não perder de vista que a organização política que um povo se outorgou livremente faz parte, e num grau eminente, da cultura deste povo, cultura que, por outro lado, ela condiciona. [...] Trata-se da limitação da civilização colonizada, supressão ou do abastardamento de tudo o que a estrutura. Como não nos admirarmos, nestas condições, com a supressão daquilo que é uma das características de qualquer civilização viva, a faculdade de renovação? (CÉSAIRE, 2011, p. 258-259).

É possível considerar a posição de Césaire radical justamente porque ele concebe a cultura colonizada como impossibilitada de renovação após a introdução da cultura colonial nos territórios colonizados. O quadro sociocultural específico a que ambas as propostas fazem referência, tanto a de Hampâté-Bâ quanto de Césaire, foi de perceber que, a partir da colonização, as formas de transmissão do conhecimento em África precisariam viver lado a lado com as formas de transmissão do conhecimento europeias, transplantadas para aquele continente por força dos movimentos exploratórios e imperialistas que irradiaram do velho continente em levas consecutivas e intermitentes desde o século XV. HampâtéBâ estava atento ao fato de que o encontro entre as duas tecnologias específicas de transmissão de conhecimento, a europeia, escrita, e as africanas orais, estava no bojo de um processo maior, a saber, o imperialismo colonizador europeu, o que, por si só, já definia a tecnologia europeia como uma forma hegemônica, a exercer domínio sobre as demais. "Tradição viva" é exatamente um esforço de valoração, pois busca, a partir de um exemplo bastante específico, provar que as formas de transmissão de conhecimento africanas, embora orais, são dotadas de uma complexidade e uma sofisticação própria, e que todo um universo cultural de conhecimento está arriscado diante da paulatina e fatal hegemonia cultural europeia. Essa diagnose é correlata ao "radicalismo" de Césaire ao prognosticar a morte desses sistemas tecnológicos em face da constante quebra de seus contextos de transmissão, ocasionada pelo avanço do colonialismo imperial europeu.

Ora, a proposta de Hampâté-Bâ deve ser vista como um princípio nevrálgico de uma discussão que ganhou diversos matizes ao longo do tempo. E alguns princípios de sua proposta precisam, hoje, ser relativizados em face de uma discussão mais alargada e de um contexto cultural e histórico já totalmente diverso 
daquele que permitiu ao etnólogo malinês produzir a sua análise. Por princípio, poderíamos empreender uma discussão acerca da validade da abrangência do princípio metonímico da análise de Hampâté-Bâ. Em que medida a análise conjuntural de uma dada dinâmica Bambara num dado momento específico é válida para estendermos as conclusões acerca dessa análise específica à realidade de todo um continente? Será possível que, a partir da análise dos Bambara do Mali, possamos obter conclusões úteis para os Xhosa da África do Sul, povos que nem na mais remota possibilidade se cruzaram, sem o mínimo de esforço comparativo? Em se tratando de uma discussão que quer, justamente, romper com paradigmas generalizantes, é possível realizar uma análise que obedeça ao princípio metonímico, a parte pelo todo, ou da sinédoque, o todo pela parte? Hampâté-Bâ está atento ao risco iminente em que incorre sua análise, e faz considerações ligeiras que devem ser observadas como uma questão de método de seu texto:

Nas tradições africanas - pela menos nas que conheço e que dizem respeito a toda a região de savana ao sul do Saara -, a palavra falada se empossava, além de um valor moral fundamental, de um caráter sagrado vinculado à sua origem divina $\mathrm{e}$ às forças ocultas nela depositadas. Agente mágico por excelência, grande vetor de "forças etéreas", não era utilizada sem prudência. (HAMPÂTÉ-BÂ, 2010, p. 169).

Ou ainda:

Como não posso discorrer com autenticidade sobre quaisquer tradições que não tenha vivido ou estudado pessoalmente - em particular as relativas aos países da floresta - tirarei os exemplos em que me apoio das tradições da savana ao sul da Saara (que antigamente era chamada de Bafur e que constituía as regiões de savana da antiga África Ocidental Francesa). (HAMPÂTÉ-BÂ, 2010, p. 179).

A questão da dificuldade metodológica que cerca a possibilidade de enunciar grandes definições que sejam verificáveis em todo o continente africano parece ser uma barreira para a qual o etnólogo estava atento. Nem nos mais longínquos avanços da antropologia estruturalista uma análise isolada permitiria extrair estruturas que se estendessem por uma realidade continental abstrata e extemporânea. Sobretudo, afirmar que toda a realidade cultural do continente africano depende, "essencialmente", de uma tecnologia oral para a transmissão do conhecimento, é ignorar casos absolutamente relevantes como, por exemplo, as figuras dja, dos 
povos Akan (distribuídos entre a Costa do Marfim, o Gana, o Benin, entre outros), comumente chamados de "pesos de bronze" (mas nem todos são "pesos" e nem todos são de "bronze"), que, nos casos figurativos, registram graficamente um conhecimento vastíssimo desse povo sobre as mais variadas áreas. A propósito, essas figuras são conhecidas pelo epíteto de "enciclopédia Akan".

Outro caso bastante relevante é também o da escrita ge'ez, um complexo conjunto de signos gráficos nativos da Etiópia, utilizado para o registro de línguas etíopes e eritreias, como o amárico, o tigré, a própria língua ge 'ez, entre outras daqueles países. ${ }^{1}$ Outro caso igualmente relevante é a imensidão do conhecimento africano veiculado em língua árabe, que representa uma quantidade imensa de testemunhos para a história de África - a Universidade de Sankore, no coração do antigo Império Mali, não será, porventura, o mais significante baluarte desse universo do Islã africano? E podemos ainda citar os infindáveis objetos da cultura material africana que representam mídias de transmissão de conhecimento e de simbologia social, passados de geração a geração, que hoje encarecem os museus europeus sob o polêmico qualificativo de "arte africana". Ignorar essas diversas tecnologias materiais e visuais de transmissão de conhecimento em nome de uma ênfase despropositada num fictício caráter "oral" válido para o continente todo é também solapar uma história e reforçar um estereótipo.

Mas não parece ser esse o caminho que segue Amadou Hampâté-Bâ quando deixa flagrante que trata de um ambiente específico da África Ocidental. Além disso, seu empenho naquele texto não é de provar que a África toda desfruta de uma essência oral comum e que partilha de valores sociais relativos a essa essência igualmente comuns. Mas é, antes, provar como, a partir do exemplo Bambara, um conhecimento que não esteja, eventualmente, registrado em formas visuais de transmissão, é também um conhecimento válido e fidedigno, fonte documental de uma realidade social e cultural sofisticada e complexa. E essa espécie de reconhecimento etnográfico e contra-hegemônico diante de culturas que foram destroçadas pelo colonialismo, isso sim, deve ser estendido a todo um continente, e mais, pode ser estendido para quaisquer espaços no mundo em que uma cultura hegemônica, com claros intuitos puramente materiais, desqualifica e deslegitima uma cultura alheia justamente pela sua diferença.

Afinal, era justamente essa a principal preocupação do etnólogo, o que, inclusive, o irmanava a Aimé Césaire em sua análise. Sua angústia, inclusive, assume uma conotação protestatória, contrária às tendências assumidas por parte

1 Considerem-se aqui também como exemplos outras formas de escritas subsaarianas, como cita KiZerbo, como o Vai, Bamum e Ajami. (KI-ZERBO, 2010). 
das elites políticas africanas em relação a um patrimônio cultural marginalizado pelos governos, que encetavam, à altura, pelo que afirma Hampâté-bâ:

Os jovens líderes "modernos" governam, com mentalidades e sistemas de lei, ou ideologias, diretamente herdados de modelos estrangeiros, povos e realidades sujeitos a outras leis e com outras mentalidades. Para exemplificar, na maioria dos territórios da antiga África ocidental francesa, o código legal elaborado logo após a independência, por nossos jovens juristas, recém-saídos das universidades francesas, está pura e simplesmente calcado no Código Napoleônico. O resultado é que a população, até então governada segundo costumes sagrados que, herdados de ancestrais, asseguravam a coesão social, não compreende por que está sendo julgada e condenada em nome de um "costume" que não é o seu, que não conhece e que não corresponde às realidades profundas do país. (HAMPÂTÉ-BÂ, 2010, p. 2010).

O centro da análise de Hampâté-Bâ consiste justamente em perceber que, outrora massacradas por uma política colonial racista, seletiva e eurocêntrica, determinadas parcelas das culturas africanas agora estavam a ser ignoradas também por uma elite política e econômica que, a propósito de considerar essas culturas como uma superstição passadiça e obscura, negava-lhes o direito a uma cidadania democrática. Culturalmente, como se essas culturas africanas não tivessem ganhado a independência na luta contra a hegemonia eurocêntrica e ocidental. A essas tendências hegemônicas, portanto, convém turvar a análise em busca de uma imobilidade cultural desses grupos, relegando-os ao estatuto de um passado remoto, a ser superado constantemente.

Será porventura esse outro debate suscitado pelo texto de Hampâté-Bâ o que nos fará retornar à crítica de Césaire: o quão imóveis e incapazes de renovaremse estarão essas culturas? Será possível considerar essas culturas fadadas à morte iminente? Será possível falar de uma modernidade científica que discrepa de uma "tradição" estanque e moribunda? É possível considerar as inúmeras formas culturais nativas de África como pertencentes a um nicho comum e próprio, que podemos então, a propósito, chamar de "tradição africana", ou "África profunda", que alimenta semelhanças internas consideráveis (como a oralidade, inclusive)?

\section{A "tradição oral"}

Embora seja utilizada de modo geral no texto de Hampâté-Bâ, a palavra "tradição" suscita maiores discussões. Com efeito, existe certa tendência latente, 
derivada, quiçá, da antropologia colonial, em isolar a África subsaariana num complexo autônomo e atomizado, que seria a África da "tradição". Exemplos como o largo trânsito de uma cultura africana escrita em língua árabe, ou a existência de um alfabeto africano etíope, devem ser descartados de uma análise dessa "tradição" justamente por sua ascendência semítica, e, portanto, "não africana". Contrária às inúmeras dinâmicas históricas que marcam um complexo trânsito entre a porção norte do continente com sua porção sul, e contrária também a uma visão que constata que a África, em suma, nunca esteve isolada na sua solidão obscura, mas sim, alimentou relações com inúmeros outros espaços (a região sudanesa com o Oriente Médio, a porção norte integrada ao complexo mediterrâneo, a África Austral com a China, a Índia e regiões da Oceania, etc.), essa visada busca identificar nesse "continente da tradição" uma harmonia autônoma, pura e independente, profundamente perturbada pela chegada de um colonizador que introduz em África todos os males. Esse tipo de pensamento acabou repousando nos usos mais extremos de um conceito de "tradição africana", que há muito tem sido questionado.

O antropólogo da Universidade de Abomey-Calavi, no Benim, Obarè Bagodo, considera como marca desse questionamento à ideia de uma "tradição africana" o seminário realizado em Cotonou entre 1987 e 1988, na então Universidade Nacional do Benim, cujo tema era, apropriadamente, Les savoirs endogènes: pistes pour une recherche, cujos resultados seriam publicados, posteriormente, em forma de um livro de autoria coletiva organizado por Paulin Hountondji e editado pelo CODESRIA em 1994. Segundo Bagodo, entre os resultados obtidos naquele seminário, saltava à vista o fato de que os participantes se propunham "(i) a reconhecer que o adjectivo 'tradicional', mesmo quando se apresenta entre aspas, é inadequado, para não dizer depreciativo, e (ii) a preferir o epíteto "endógeno" (BAGODO, 2012, p. 53). Para justificar os motivos que levavam os estudiosos a essas conclusões, Bagodo cita textualmente a alocução de Hountondji, que transcrevemos aqui:

O adjectivo "tradicional" não é inocente senão aparentemente. Utilizado de forma espontânea, por oposição a "moderno", veicula a ideia obscura de um corte radical entre o antigo e o novo. Atira, assim, o antigo para um quadro estático, uniforme, sem história e sem profundidade, em que todos os pontos parecem rigorosamente contemporâneos, reservando para a categoria do moderno o prestígio da mudança, ou, numa palavra, da historicidade. (HOUNTONDJI apud BAGODO, 2012, p. 53). 
A dissertação de Obarè Bagodo investe pesado no sentido de, cada vez mais, desconsiderar os repertórios culturais africanos como "tradição", oposta a uma "modernidade", e sim, como saberes e saberes-fazer endógenos, passíveis de processos de atualização, automodernização e reciclagens próprias e dinâmicas consoantes ao tempo e ao espaço em que se inserem - ou seja, atribui-lhes, exatamente, uma historicidade que o conceito de "tradição" parece não poder abarcar até certo ponto. A essa oposição aparente entre modernidade e tradição, Bagodo chama de "falsa antinomia" (BAGODO, 2012, p. 54), buscando, por sua vez, historicizar mesmo sua origem a partir do decreto proferido pelo imperialismo europeu "triunfalista, condescendente e egoísta", num processo que durou do século XVI até o XIX, de que as outras culturas que encontrava em sua aventura colonial "não passavam de tradicionais, condenadas a uma extinção irrefragável" (BAGODO, 2012, p. 55). A mesma antinomia de origens coloniais parece ter sobrevivido a todos os impulsos descolonizadores das ciências e das epistemologias, indo depositar-se numa palavra de "aparente inocência", qual seja "tradição", oposta a modernidade.

Curiosamente, outro pesquisador da Universidade de Abomey-Calavi, Geoffroy Botoyiyè, afirma justamente que o repertório cultural endógeno africano, por não estar preservado numa forma fixa visual como a escrita, mas sim dependente de contextos de elocução próprios, está mais volúvel a uma movimentação dinâmica de transformações, adaptações e adequações que um repertório cultural escrito. Por isso mesmo, Botoyiyè afirma que a expressão "tradição oral" é um paradoxo por princípio. Segundo afirma: "na prática, só há tradição se houver escrita" (BOTOYIYÈ, 2012, p. 349). Ainda que não seja possível confiar totalmente na permanência e na imutabilidade dos textos escritos como Botoyiyè propõe (e os graves problemas filológicos que cercam textos antigos que nos provem o quanto edições e testemunhos escritos estão à mercê de transformações ao longo do tempo), vale a pena considerar a ênfase do pesquisador acerca do caráter mutável e histórico das culturas endógenas transmitidas por vias acústicas, o que depõe contra a utilização do termo "tradição" como significando algo absolutamente harmônico, permanente e imutável, oposto a uma modernidade.

Com uma argumentação aguda que mobiliza grande repertório da filosofia da ciência, Bagodo busca derrubar os mitos que cercam a oposição entre uma possível modernidade científica e uma tradição imóvel africana. Mostrando como, dentro mesmo dessa modernidade científica ocidental, aqueles antigos critérios da ciência moderna foram postos em xeque, como a distinção entre sujeito e objeto, a objetividade científica, a causalidade, o rigor lógico da linguagem, entre outros 
aspectos, Bagodo busca mostrar que a modernidade científica tem fundamentos teóricos que a tornam mais do que apta a reconhecer inúmeros avanços epistemológicos, filosóficos e científicos elaborados a partir dos saberes e saberesfazer endógenos africanos, que são largamente enumerados e exemplificados em seu texto. Segundo afirma, a concepção e aplicação multidimensional da modernidade científica permitem relativizar a falsa antinomia habitual entre as tradições dos saberes de África e "as acções constitutivas da ciência actual" (BAGODO, 2012, p. 59).

Pois então, restaria a pergunta: se a modernidade científica tem condições metodológicas de reconhecer a elaboração dos saberes e saberes-fazer do conhecimento africano endógeno, quais sãos os motivos que continuam, até os nossos dias, a relegar a esses saberes endógenos sua marginalização e a constante indiferença com que precisam conviver? Afinal, quando investe em perceber quais são os desafios do século XXI para os saberes endógenos, Bagodo até apresenta propostas consideravelmente otimistas, pelo que afirma:

Na medida em que o desenvolvimento técnico e cultural foi sempre um processo cumulativo, em África [...] o [presente] estudo toma em consideração todos os sabres e saberes-fazer pré-históricos ou históricos, antigos, pré-coloniais ou recentes, que contribuam para o funcionamento das nossas sociedades contemporâneas. Esta funcionalidade mantém-se essencialmente activa mesmo nas suas dimensões museográficas, igualmente, a utilização contemporânea dos nossos saberes e saberes-fazer se mantém activa e preponderante em muitas áreas. (BAGODO, 2012, p. 60).

Percebe-se aqui o quão diferente é a visão de Bagodo daquela de Césaire. Um decretava a morte das culturas africanas em face da colonização, o outro, algumas décadas depois, afirma que a funcionalidade dos saberes endógenos africanos continua ativa, mesmo nas suas dimensões museográficas. Isso, no entanto, não anula o desafio que é a existência democrática de uma cidadania civil para esses saberes dentro dos modernos Estados africanos. E nesse ponto, exatamente, reside uma ligeira crítica do texto de Bagodo, que acaba sendo uma crítica que também atravessou o texto de Amadou Hampâté-Bâ, também o texto de Geoffroy Botoyiyè, e, de alguma forma, também do texto de Césaire. Ou seja, qual futuro para uma confluência definitiva entre a modernidade científica e os saberes africanos endógenos que não passe por políticas de gestão que promovam o intercâmbio, a pesquisa, o registro, a tradução, a transcrição e contato entre culturas e instituições de saberes? Quais os avanços que são possíveis de serem observados atualmente neste sentido? Vejamos o que diz o arqueólogo: 
Enquanto tal, esta abordagem permite confiar que com a sinergia entre uma gestão adequada dos patrimônios endógenos vivos e a modernidade científica contemporânea, a África do século XXI poderá, enfim, libertar-se da armadilha da marginalização e promover uma neocultura inovadora e competitiva. (BAGODO, 2012, p. 60).

Também Botoyiyè parecia deslocar a discussão teórica presente em seu texto para um apelo político que pudesse solucionar os problemas de adequação, legitimação e capitalização científica dos patrimônios culturais endógenos africanos, pelo que afirma:

A recuperação, ou melhor, a transcrição dos conhecimentos e dos procedimentos junto dos detentores locais de saberes [endógenos] é o meio de capitalizar o depósito dos saberes orais. Isto deve ser uma tarefa urgente inscrita no programa das instituições de investigação em África. [...] Se desejamos valorizar os saberes endógenos, não há mais do que uma via, é encontrar para eles um lugar nos canais actuais de produção do saber. [...] Será ela possível sem a refundação do sistema actual da investigação em África? (BOTOYIYÈ, 2012, p. 349).

Ao ouvirmos esses apelos por uma política de gestão patrimonial, pensamos, de imediato, acerca do quão difícil tem sido mesmo a consolidação dos sistemas de investigação - os institutos, as universidades - em África. Se mesmo a consolidação dessas instituições passa por carências extremas (cf. a esse respeito HOUNTONDJI, 2008, p. 157), o que deveríamos esperar de uma política mais democrática e mais etnográfica de atuação? Pelo menos no que tange aos países africanos de língua oficial portuguesa, os problemas de gestão do patrimônio endógeno são gravíssimos, com escassas e rarefeitas exceções. Talvez diante da flagrante falta de vontade política, valha a pena confiar num percurso teórico que continue investindo na ideia de uma "África profunda" mergulhada numa "tradição" composta por qualquer coisa a que se chame "oralidade" - pois, como parece óbvio, os percursos teóricos não são totalmente abstrativos das vulgatas políticas e dos discursos oficiais que regem a hegemonia do poder. Relegada ao seu eterno estatuto imóvel, sem história, é possível, inclusive, perceber conflitos entre essa "tradição ancestral" - porque, afinal, está no passado -, e as dinâmicas históricas desses países no presente. Afinal, enxergar-lhe a modernidade, a historicidade e o imenso potencial científico que esses saberes endógenos preservam, é assumir a indiferença, a intolerância e a intransigência autoritária. 
Não que não exista uma dimensão de África específica cujos conhecimentos sejam transmitidos de geração a geração através da cultura acústica, e que guardem relativa distância dos modos de conhecimento ocidentais. $\mathrm{O}$ que colocamos em questão aqui é que o uso indiscriminado de conceitos como "tradição oral" acarreta muito mais problemas do que parece, e se o seu uso não estiver atento a essa problemática, incorrerá no risco de ser generalizante em demasia para um conjunto humano tão vasto e tão heterogêneo como o continente africano. Sobretudo quando o objetivo deste uso é romper com paradigmas generalizantes coloniais e preconceituosos. Não se questiona um paradigma generalizante pela sua mera substituição, mesmo que o novo seja mais positivo e idealizador que o antigo - ambos desconhecem a especificidade, autonomia e a diversidade.

\section{Uma postura da crítica literária}

As relações possíveis entre a literatura moçambicana de língua portuguesa e os repertórios culturais endógenos transmitidos por vias acústicas devem ser vistas, antes de tudo, em vista de sua historicidade. Uma literatura produzida na década de 1930 não guarda as mesmas relações com o repertório endógeno acústico que uma literatura produzida na década de 1950. Da mesma forma, os paradigmas que marcaram a produção da década de 1950 não devem ser considerados como linhas mestras e diferenciais de uma literatura que se estenderá por mais décadas a seguir em diferentes quadros socio-históricos. Com o objetivo de percorrer somente alguns momentos de virada no interior dessa literatura, propomos aqui uma revisita a alguns momentos bastante pontuais dessa produção.

As primeiras manifestações de uma escrita em língua portuguesa produzidas no espaço colonial de Moçambique foram gestadas no ambiente do assimilacionismo português em África, que agregava um contingente populacional dentro de uma educação que buscava, ao menos em tese, inserir os africanos, juridicamente considerados "indígenas", na cultura ocidental, europeia e portuguesa. Alinhase a essa problemática educacional também um problema social e ideológico de construir uma visada crítica acerca das próprias condições de vida das populações sob um regime colonialista - muito da crítica política gerada no interior do protonacionalismo, no entanto, encontrava limites para suas alternativas nas estruturas do Estado colonial português. Para isso, cumpre realizar uma rápida análise das condições jurídicas que ratificavam as divisões sociais na sociedade colonial. O grupo dos colonizados era dividido em dois subgrupos: o do africano nativo, o indígena; e o daquele que era considerado "civilizado", porque "sabia 
falar português, estava desligado de todos os costumes tribais (sic) e que tinha emprego regular e remunerado", como bem analisa o pensador moçambicano Eduardo Mondlane (MONDLANE apud SANCHES, 2011, p. 312).

Essas eram as bases do que Mondlane chama de "sistema do assimilado", que, na verdade, se prestou a criar minorias letradas dentro da sociedade moçambicana. A assimilação portuguesa tinha bases antigas depositadas na ideologia da missão evangelizadora do português entre os "gentios", desde as antigas formas de colonialismo. Não por acaso, as "missões" foram instituições formadoras de assimilados. Mas, em relação ao colonialismo ligado ao imperialismo do século XIX, a assimilação, a partir do seu estatuto jurídico, produziu durante todos os anos da colonização imperialista diversas gerações de assimilados na sociedade moçambicana. A condição do assimilado, portanto, inserido num sistema jurídico e social que desvalorizava cada vez mais sua cultura e a considerava como "nãocivilização", mesmo quando tomava a consciência da exploração, deveria estar dentro dos limites proporcionados pelo sistema que o assimilava, o que justificaria os limites da crítica do protonacionalismo:

\begin{abstract}
Mas a firme convicção na capacidade dos negros em guindaremse às altas esferas do saber acompanha-se de uma atitude ambivalente, já que ela pressupõe que os "indígenas" rejeitem os seus valores próprios e "saiam" do estado de "não cultura" para se integrarem num quadro civilizacional preciso - o molde ocidental. (ANDRADE, 1997, p. 93 - destaques do autor).
\end{abstract}

A partir dos anos de 1940, no entanto, essas manifestações consideradas como protonacionalistas vão desembocar num ponto de viragem que tomará feições de um novo tipo de pensamento crítico em relação à condição colonial. Este é o período que veria o fim das limitações apresentadas pelos antigos assimilados protonacionalistas, e as manifestações críticas no interior da sociedade moçambicana assumirão a forma de um novo nacionalismo, que, através de continuidades e rupturas, culminarão num pensamento verticalmente crítico a respeito da colonização portuguesa em África, segundo afirma Mário Pinto de Andrade:

A linha de continuidade situa-se no plano dos temas essenciais do discurso político e da práxis, considerados num outro contexto e carregados de conteúdos diferentes. Com efeito, a problemática inerente ao sistema colonial recolocar-se-á durante largo tempo em termos da dicotomia indígena/assimilado, da permanência apenas dissimulada do trabalho obrigatório, do esbulho das terras 
ou do acesso à instrução. [...] Mas o protonacionalismo, na sua essência, foi produtor de um discurso com uma finalidade ilusória: assumindo-se como negros cultos, no molde ocidental, sujeitos da nação portuguesa e legalistas, esses ideólogos [...] não tinham atingido o grau crítico de compreensão lógica do sistema colonial português. E aí reside, precisamente, o ponto de ruptura que será expresso pela geração que fará a sua entrada na cena da história, nos anos imediatos à segunda guerra mundial. (ANDRADE, 1997, p. 185-186).

A explicação sociológica desse novo tipo de pensamento político crítico acerca da colonização passa pela compreensão de certo tipo de processo social assimilativo que escapava ao controle efetivo do Estado português e dos aparatos de Estado como as igrejas e as missões. Trata-se daquilo que o sociólogo moçambicano José Luís Cabaço chama de surgimento de "populações periurbanas" (CABAÇO, 2009, p. 139), aglomeradas em bolsões suburbanos ao redor das grandes cidades, cuja presença na cidade consistia numa oferta de mão de obra barata, cada vez mais solicitada por conta da intensa urbanização que assistiu Moçambique desde os primeiros decênios do século XX. Esses bolsões suburbanos terão seus nomes inscritos miticamente na história literária moçambicana como Xipamanine, Munhuana, Catembe, Mafalala, Malanga, Minkhokweni, Malhangalene, entre outros. Segundo Cabaço:

O crescimento da economia colonial estimulava a urbanização de contingentes cada vez mais numerosos de camponeses que o Governo colonial, não obstante as restrições administrativas e a repressão, era impotente para conter. Essa migração de gente do campo tradicionalista para um habitat urbano onde era forte a presença da modernidade ocidental foi dando origem a um novo tipo sociocultural que o maniqueísmo estreito da colonização em Moçambique insistia em continuar remetendo para a classificação residual de indigena: era o africano da periferia dos centros urbanos que [...] se encontrava distante de sua comunidade, desenquadrado das relações hierárquicas, dos vínculos tradicionais, das práticas consuetudinárias dos espaços rurais. [...] Nesse parcial desenraizamento, ele não rompia, contudo, com suas origens e era sobre tais referências que construía as várias identidades na nova situação: nos subúrbios urbanos, reestruturava-se em sistemas de organização da vida que refletiam a simbiose dos dois universos culturais em que orbitava. (CABAÇO, 2009, p. 139 - destaques do autor). 
Esse novo quadro social gerará um novo contexto discursivo que verá nascer uma geração de artistas que apresentará articulações estéticas e, concomitantemente, políticas, consideravelmente inovadoras. Com efeito, apropriando-se de mídias ocidentais, como a música produzida com instrumentos europeus, a escrita livre numa língua portuguesa apropriada, a pintura em telas, Moçambique viu surgir nesse período uma arte empenhada, que transcendia as pertenças culturais endógenas, mas recusava o estatuto de "quase-português" obtido através da assimilação antiga - reconheciam-se, a priori, os artistas, como moçambicanos, e mais do que isso, reivindicavam o direito a essa pertença. Esse período viu surgir nomes basilares da cultura moçambicana como o pintor Valente Malangatana Ngwenya, a ascensão do ritmo marrabenta, através de nomes como Fany Mpfumo, na prosa artística, nomes como o de Luís Bernardo Honwana, Orlando Mendes e, na poesia, sobretudo, José Craveirinha e Noémia de Sousa.

Essa arte, que a propósito de um fenômeno semelhante, ocorrido noutra latitude do mundo colonial, o prof. Antonio Candido chamaria de "arte empenhada" (CANDIDO, 2013, p. 29), carregará em sua configuração estética, sobretudo, uma forma de reflexão sobre as próprias condições de vida dos habitantes de uma sociedade ainda colonial, apresentando uma ótica e uma perspectiva que se reconhecerá, finalmente, como uma comunidade autônoma diferente de Portugal. Essa perspectiva de autonomia se verificará em diversas chaves e em diversas formas de manifestação no interior da cada obra - e vale, para isso, empreender um esforço crítico que analise em cada peça e cada obra de arte a busca desses traços de perspectivas e diferentes formas de reflexão acerca dum pensamento autonomista.

Será especificamente a partir desse momento que se poderá perceber uma melhor organização e sistematização de um corpo de textos que irá se comprometer com a postura da produção de uma literatura moçambicana. Serão nomes como Orlando Mendes, Noémia de Sousa, José Craveirinha que produzirão uma obra que se quererá esteticamente moçambicana. Ao pautarem sua produção pela tomada de uma consciência crítica acerca do domínio político português no interior da colônia, viam-se identitariamente diferentes dos portugueses, o que, até então, não teria ocorrido com os antigos assimilados dos tempos do protonacionalismo, como propunha Mário Pinto de Andrade. Ao perceberem-se em contraste com o português, os escritores moçambicanos, ao mesmo tempo, estavam distantes da pertença cultural especificamente endógena - já que não habitavam mais o espaço da aldeia e só tinham acesso àquelas culturas conforme alguns (ou muitos) traços delas ainda se preservavam no cotidiano da periferia. 
As formas estéticas específicas que a produção literária assumiu, que podem ser úteis para uma interpretação de sentido identitário, são sobremaneira variadas, de autor para autor, e de obra para obra, de modo que dependeríamos de várias análises para percebermos como a chave do surgimento de uma identidade nova, moçambicana, no seio dessas populações periurbanas, torna-se operacional para uma interpretação literária. Como, no entanto, o acesso dessa população aos bens culturais ocidentais estava livre dos códigos restritivos impostos pela antiga assimilação oficial, os signos se subvertem de uma forma bastante inovadora, em diversos níveis. Num momento específico da história, em que as forças coloniais impunham seu controle político somado à coerção cultural racista e limitadora, deixar transparecer esteticamente, no texto, uma identidade específica, diferente da portuguesa, justamente por conta de um contato de proximidade com as culturas endógenas acústicas, se fazia em caráter de subversão e urgência.

Desse modo, produções literárias como a de Noémia de Sousa apelarão para um sentido insistente de autoidentificação, através de diversos dispositivos estéticos - como a estrutura dialogal com um outro estranho e diferente e a autodescrição que busca definições físicas, culturais e ideológicas - que atravessam várias comunidades culturais diferentes de um ambiente que se percebe a partir dos traços definidos pela colônia de Moçambique. Ou seja, uma consciência de uma identidade calcada no espaço geográfico colonial - Moçambique -, mas que transcende o unitarismo de uma só pertença etnocultural em direção a um sujeito enunciador coletivo, são sinais, na poética da autora, de uma consciência que desembocará na construção de um nacionalismo. Esse nacionalismo estará definitivamente nomeado na poética de José Craveirinha, quando este sujeito lírico, expandido e coletivo, alcança a dimensão de uma comunidade nacional que está porvir, ou a "nação que ainda não existe".

Sem objetivar uma análise específica de poemas exemplares da produção desses dois autores, é possível notar, no entanto, que a partir da insistência desses autores na construção quase pictórica de uma poética que se quererá eminentemente moçambicana, diversos traços culturais endógenos atravessarão a construção poética: desde o nível da linguagem, com a extrapolação do uso de termos diretamente transcritos, maiormente da língua Ronga e de outras línguas do sul de Moçambique, ao nível das referências, com alusões, analogias e metáforas mais que explícitas a diversos grupos no interior do território moçambicano, como os chopes, macondes, entre outros, até o nível da organização lógico discursiva, que se construirá a partir de estruturas dialógicas acústicas específicas, como é o caso do karingana wa karingana, prática discursiva própria dos Rongas, que é transcrita 
esteticamente para o interior da poética de Craveirinha, tornando-se praticamente uma tópica de sua produção, e por extensão, de toda a literatura moçambicana subsequente. Outras formas de autoidentificação de um sujeito enunciador expandido, porém, podem ser vistas, como é o caso de Noémia de Sousa e sua dimensão étnica coletiva, em certos poemas em que o eu lírico se autoenuncia como "negro" (mais apropriadamente "negra"), pertencente a um corpo negro coletivo de todo o mundo, e ainda a questão do trabalho, que em ambos os poetas irmana este sujeito lírico a um corpo social de trabalhadores na dimensão da exploração e do trabalho alienado.

Nesse sentido, tanto uma identidade social nova (a "moçambicanidade") aflora do interior dos textos literários, como os próprios textos são, a um tempo, um dos motores de produção dessa identidade. José Luís Cabaço esclarece alguns pontos acerca dessas coordenadas do projeto literário de então:

A dialética da formação da identidade exige a clareza sobre os pontos de partida. E se são diversos os caminhos percorridos pelos nossos escritores, é mais ou menos pacífico para todos eles que a literatura moçambicana caminha, com maior ou menor ênfase, sobre dois carris: a língua portuguesa, como meio de expressão escrita e processo de inculturação - não como referente intertextual marcante - e a tradição oral (e agora a tradição inventada do processo revolucionário) como permanente busca de uma intertextualidade nacional. (CABAÇO, 2004, p. 66).

Resta, pois, saber se o modelo específico dessa literatura que precisava conviver com a tomada de uma consciência da diferença - para ficar nos termos de Cabaço - pode ser ampliada para além desse momento. Como vimos, a proposta analítica de Cabaço prognosticava que a literatura moçambicana, preservadas as variações e diferenças, caminhava sobre o que ele chama de "dois carris", a saber, o repertório próprio adjacente ao uso da língua portuguesa, e depois, o segundo carril, composto por dois elementos distintos, quais sejam, (i) uma tradição oral que se metamorfoseia numa (ii) "tradição inventada do processo revolucionário". Ora, esses dois elementos que compõem um só "carril" na equação de Cabaço, do ponto de vista da história da literatura atualmente, precisa ser mais bem destrinchado. Ou seja, é preciso perceber as nuances de diferença entre o que é considerado, num momento, de "tradição oral" e o que é que pode ser considerado como "tradição inventada" na literatura própria do processo revolucionário. As tendências seguintes da literatura moçambicana dizem respeito diretamente aos acontecimentos que se seguem à guerra iniciada pela FRELIMO contra as forças coloniais portuguesas em 1964, e é esse processo, precisamente, que Cabaço chama de "processo revolucionário". 
Um corpus exemplar que compõe essa literatura atribuída como resultante do processo revolucionário pode ser encontrado na coletânea produzida no âmbito da guerra pela independência encetada pela FRELIMO, a chamada Poesia de combate (1971). Essa antologia teve sua continuidade na Poesia de combate II, editada já após a independência, em 1977, e foi seguida de uma reedição da primeira antologia, ligeiramente modificada, em 1979, que receberia então o nome de Poesia de combate I. Já em 1980 vem a lume a Poesia de combate III, e outras antologias posteriores não tão paradigmáticas em que o modelo proposto desde a primeira antologia da Poesia de combate era seguido fielmente. Pois essa poesia produzida neste período objetivava, precisamente, compor-se de um corpo literário que se afinasse apropriadamente como poesia didática para cumprir com os objetivos da revolução a que a independência de Moçambique se tornara. A propósito, a primeira coletânea de 1971 fora publicada por um órgão intitulado Departamento de Educação e Cultura da Frente de Libertação de Moçambique FRELIMO -, e as outras duas antologias, de 1977 e 1979, respectivamente, por outro órgão intitulado Departamento de Trabalho Ideológico do Partido.

Justamente por objetivar criar um ambiente de afinação absoluta da poesia com os objetivos da revolução é que certos conteúdos e formatos tornaram-se programáticos para essa produção. Essa produção recebia ainda as ressonâncias de outras produções literárias relacionadas com os programas de Estado para arte e estética realizados em outros lugares do mundo, em contextos de revoluções socialistas, como o realismo socialista soviético, fomentado por Andrei Jdanov (1896 - 1948), durante o período stalinista da União Soviética (1922 - 1953). No caso do realismo socialista soviético, tratava-se, especificamente, de criar uma literatura que funcionasse como uma "engenharia de almas", uma forma de controle intelectual a partir da arte para que a obra, uma vez rejeitados os valores meramente estéticos, vistos como puro diletantismo burguês, representasse a "realidade objetiva", mas, amiúde, a "realidade do processo revolucionário". (NAPOLITANO, 1997, p. 15). Assim, valores caros a essa produção passaram a representar diretrizes normativas instantes, sobre as quais qualquer escritor deveria manter atenta vigilância, como uma observação atenta à correição ideológica como definida pelo partido, acessibilidade da obra para todos os públicos (sobretudo a grande massa iletrada que compunha a população russa aquando da revolução), e outros caracteres de cariz nacionalista.

No contexto moçambicano essas ideias tiveram uma recepção bastante oportuna, sobretudo a partir do $1^{\circ}$ Seminário Cultural da FRELIMO, realizado entre dezembro de 1971 e janeiro de 1972, cujos objetivos, mais do que uma avaliação 
da produção poética moçambicana produzida até aqui (representada, sobretudo, pelo corpus da Poesia de Combate), era elaborar diretrizes para uma verdadeira poesia que se considerasse revolucionária e moçambicana. Neste sentido, as diretrizes moçambicanas para o que se queria como poesia revolucionária foram elaboradas, mas, também, alguma teorização acerca do que seria a própria poesia revelava certa preocupação com a divulgação poética num contexto em que não só o iletramento era um problema a ser transposto, mas o próprio acesso à língua portuguesa (BASTO, 2006, p. 125-126).

Nesse sentido, temáticas como os episódios da guerra nas matas eram vistas como motes de maior valor revolucionário que temas como poemas de amor, rechaçados como puro ócio burguês, e alienados. Com efeito, o conceito de poesia que as coletâneas da Poesia de Combate transmitem a partir de seus prefácios é bastante revelador de características como o alinhamento da figura do poeta à figura do guerrilheiro, da poesia como palavra de ordem, e do questionamento dos valores considerados "burgueses", como o intimismo ou até mesmo uma tendência de supressão ou desconsideração da autoria (existem poemas nas antologias que aparecem sem autoria creditada), e apologia ao Homem Novo moçambicano. Vejamos alguns trechos:

São poemas de militantes da FRELIMO, todos eles diretamente engajados na luta armada de libertação nacional. Porque é esta a característica essencial da poesia moçambicana de hoje: há identificação absoluta entre a prática revolucionária e a sensibilidade do poeta. [...] É por isso que a poesia é também uma palavra de ordem. Como a palavra de ordem, ela nasce da necessidade, da realidade. Enquanto no colonialismo e no capitalismo, a cultura, a poesia, eram divertimentos para as horas de ociosidade dos ricos, a nossa poesia de hoje é uma necessidade. [Prefácio da Poesia de combate I]

Nesta poesia de combate cada poema é, acima de tudo, participação. E essa participação só surge quando o combatente se torna o Homem Novo, o Povo, a Classe. [Prefácio da Poesia de combate II]

Ora, o Homem Novo está exatamente no ponto chave de compreensão do modo pelo qual este tipo de prática poética deste período da história literária de Moçambique se relacionaria com as culturas endógenas. A questão do homem novo é, na verdade, uma reverberação de ideias políticas que vinham das diversas formas que assumiu o socialismo real praticado na União Soviética e na China, além do socialismo da Tanzânia encabeçado por Julius Nyerere. A FRELIMO, de uma forma ou de outra, deixou-se penetrar por diversas dessas tendências, construindo uma 
linha de atuação própria, com fortes traços maoístas e stalinistas (MALOA, 2011, p. 87). Tratava-se de uma tendência de ação cultural que, quando alçada a política de governo, representou uma cisão profunda no seio da sociedade moçambicana. A força centrípeta da construção do Estado moçambicano, que se fazia sentir através de uma coerção cultural que privilegiava uma nova forma de identidade em detrimento das inúmeras culturas africanas, acabou por fazer com que o nacionalismo moçambicano fosse mais a expressão de um Estado jurídico que se estava a construir do que, como no início da luta armada, a expressão de um anseio coletivo de libertação nacional e construção de um Estado no espaço colonial (CAHEN, 2005, p. 41).

Diante desse contexto, a pertença etnocultural diferente daquela proposta pelo Homem Novo era um perigo demasiadamente grande para ser exaltada como um valor nacional. Tornava-se, por assim dizer, um tabu, um local interdito para as discussões públicas - inclusive na literatura. Da mesma forma, diversas práticas culturais específicas passaram a ser consideradas como "obscurantismo", como um tipo de "superstição" a ser transcendido, ultrapassado e eventualmente negado. Evidentemente, esse tipo de prática de engenharia social revelava as tensões entre um projeto modernizante de Estado e de sociedade, empreendido pelas elites que governavam Moçambique, e sua habilidade em negociar ou não com as diversas formas culturais que se encontravam naquele espaço colonial e que, agora, deveria ser um país.

Assim, não será possível ainda dizer que aquele tipo de nacionalismo independentista, que autoafirmava uma identidade cultural específica e "moçambicana" em contraposição a um regime opressor e etnocêntrico, justamente a partir de dados culturais que eram valorizados, ainda continuasse ativo da mesma forma na produção literária desse período. O que o novo nacionalismo revolucionário do final da década de 1960 e 1970 prognosticava, sobretudo, a partir da literatura oficial das coletâneas da Poesia de combate, era justamente uma transcendência do dado cultural específico - e será grande a possibilidade de vermos traços culturais endógenos do repertório acústico dos grupos moçambicanos serem negados nessa produção. ${ }^{2} \mathrm{O}$ que naquela chave de leitura proposta no início consistia somente em um "carril", agora podemos ver que se trata de diversos carris, diferentes o suficiente para não serem confundidos: o espírito autonomista que inspirou a produção poética da década de 1950 e início da década de 1960 será consideravelmente diferente do nacionalismo revolucionário que pauta a produção poética oficial da década de 1970 e depois.

2 Veja-se, por exemplo, a negação da prática do xicuembo em poemas como "Obscurantismo", de Armando Guebuza, presente na coletânea Poesia de combate II. 
Mas, ainda assim, precisamos aumentar mais uma vez, ad infinitum, o número dos "carris" desta discussão com a inclusão de toda a produção que se segue a partir da década de 1980. Episódios pontuais como o concurso literário de 1980, organizado pela Revista Tempo, que não atribui o prêmio a nenhum dos concorrentes justamente por julgarem que a produção apresentada "encontravase aquém" de qualquer coisa que apresentasse um mínimo de trabalho artístico com palavras (BASTO, 2006, p. 25), já mostrava que o modelo didático da poesia oficial estava em questão e encontrava-se próximo de um desgaste. Há que se considerar, sobretudo, um grupo específico de intelectuais e escritores que iniciam suas atividades artísticas justamente a partir desse período. Refere-se, precisamente, a Luís Carlos Patraquim, com a publicação de seu livro Monção, de 1980, e posteriormente os nomes que estarão aliados à chamada geração da Revista Charrua, como Marcelo Panguana, Helder Muteia, Eduardo White, Ungulani Ba Ka Khosa. É preciso também fazer referência a nomes como Calane da Silva, Lilia Momplé, Mia Couto e Albino Magaia, que iniciam suas atividades nesta década de 1980, mas não estão necessariamente relacionados com a Charrua, e também nomes que publicarão a partir da década de 1990, como Paulina Chiziane, Nelson Saúte e João Paulo Borges Coelho.

Inaugurando, sobretudo, a escrita em prosa em Moçambique, nesta década de 1980, esses nomes todos começaram a produzir com um nível de reflexão estética bastante sofisticado e variado entre si. Consideravelmente alheios às diretrizes revolucionárias da poesia oficial, distenderam o arco de seu comprometimento ideológico construindo um trabalho bastante diverso, mas com marca à nova possibilidade de produzir uma crítica contundente ao centralismo e autoritarismo do Estado, e, sobretudo, a irreverência da escrita para além de paradigmas, doutrinas e diretrizes cerradas. Com poucas exceções, tratamos agora de uma geração de escritores iminentemente urbana, escolarizada, e com a língua portuguesa como língua materna. Será notável justamente como o apelo às culturas endógenas acústicas seja recorrente nas obras desses escritores, sobretudo como forma de protesto, agora não contra um colonialismo etnocêntrico, mas sim contra um Estado centralista e autoritário demais para reconhecer as diversas pertenças que compõem o espaço sob sua gestão. Esse recurso aos dados específicos de culturas endógenas, no entanto, ao invés de ser visto agora como uma petição de princípio da crítica, deve ser visto como um recurso que toma lado de diversos outros, a que os escritores podem ou não lançar mão. 


\section{Considerações finais}

Contra as generalizações que o senso comum produz acerca de África, fruto do imperialismo eurocêntrico que ainda voga nas mentes e na imaginação dos espaços pós-imperiais, as ciências humanas precisam apelar sempre para a noção quase óbvia de que um espaço humano das proporções de um continente não poderia nunca produzir uma cultura homogênea o suficiente para ser considerada em bloco. Mas as ciências humanas acerca de África não extraem seus argumentos a partir do senso comum, a menos que deseje estudá-lo, por sua vez. As ciências humanas precisam extrair seus argumentos de pesquisas e considerações teóricas específicas. Nesse sentido, acreditar que a África toda conspira numa espécie de essência formada por uma "tradição oral" acarreta mais problemas teóricos que soluções, incorrendo num risco grave de se criar outra generalização, como aquelas do senso comum.

Não temos aqui discutido o valor ou não de uma cultura endógena acústica em face da produção literária escrita, muito pelo contrário. A própria literatura pode demonstrar, em momentos específicos para a crítica, o quanto esse repertório cultural endógeno atravessa a escrita numa língua cuja origem é, a propósito, europeia, e cujo histórico africano está justamente ligado à colonização e à dominação. O que se propõe aqui é que essa relação entre um repertório cultural endógeno e a escrita literária em línguas de origens europeias seja, efetivamente, vista em face de sua historicidade e de sua especificidade. A elaboração, no campo da crítica, de constantes estéticas para uma produção tão larga e tão variada, deveria ser feita em face de metodologias comparativas abrangentes, e não em face de "chaves de leitura", ou "essência de textos" (literatura "e" oralidade, por exemplo).

Uma vez que comparações abrangentes não corroborariam a "chave de literatura", como pudemos ver no caso da Poesia de combate ou da literatura urbana da década de 1980, a chave de leitura precisa então ser vista com um mínimo de crítica. A própria insistência no caráter "europeu” da língua portuguesa em Moçambique parece desconsiderar o quão "moçambicana" é aquela variante, ou quão "angolana" é outra variante do português, assim como a nossa variante é "brasileira", e nenhum crítico literário põe isso em causa. Os escritores africanos todos podem escrever sobre quaisquer temas e de quaisquer formas, sem que exista uma pretensa forma crítica para validar a africanidade de seu escrito, seja o que se chama "tradição", seja o que se chama "oralidade", seja o que se chama "ancestralidade", ou sejam quaisquer outros paradigmas generalizantes que se 
venham produzir acerca de África. O continente africano continuará mostrando para o mundo, em pleno século XXI, muito mais diferenças que semelhanças.

\begin{abstract}
The use of the term "African oral tradition" makes direct reference to a theoretical discussion that mobilizes more questions than answers. Taking into account some recent studies of anthropology and African archeology, this article intends to theoretically revisit a few moments of discussion about the existence of an African tradition and an African orality, and then discuss the applicability of these concepts within the Mozambican literary criticism from a diachronic and historical sight. The aim is to obtain information for an interdisciplinary reflection of key concepts for the understanding of intercultural dialogue surrounding the Mozambican literature.
\end{abstract}

Keywords: Oral tradition. Mozambican literature. Endogenous knowledge. Acoustic cultures.

\title{
Referências
}

ANDRADE, Mário Pinto de. Origens do nacionalismo africano. Lisboa, Publicações Dom Quixote, 1997.

BAGODO, Obarè. Saberes endógenos e desafios da modernidade científica: reflexões de um arqueólogo. In: HOUNTOUNDJI, Paulin (Org.). O antigo e o moderno: a produção do saber na África contemporânea. Luanda: Edições Mulemba, 2012.

BASTO, Maria Benedita. A guerra das escritas: literatura, nação e teoria póscolonial em Moçambique. Lisboa: Vendaval, 2006.

BOTOYIYÈ, Geoffroy. O que pode a escrita? In: HOUNTOUNDJI, Paulin (Org.). O antigo e o moderno: a produção do saber na África contemporânea. Luanda: Edições Mulemba, 2012.

CABAÇO, José Luís. Moçambique: identidade, colonialismo e libertação. São Paulo: Editora Unesp, 2009.

CABAÇO, José Luís. A questão da diferença na literatura moçambicana. In: Via Atlântica, São Paulo, n. 7, 2004.

CAHEN, Michel. Luta de emancipação anti-colonial ou movimento de libertação nacional? Processo histórico e discurso ideológico - o caso das colônias portuguesas e de Moçambique, em particular. Africana Studia, Porto, n. 8, 2005. 
CANDIDO, Antonio. Formação da literatura brasileira: momentos decisivos. Rio de Janeiro: Ouro sobre azul, 2013.

CÉSAIRE, Aimé. Cultura e colonização. In: SANCHES, Manuela Ribeiro (Org.). As malhas que os impérios tecem. Lisboa: Edições 70, 2011.

HAMPÂTÉ-BÂ, Amadou. A tradição viva. In: História geral da África, I: Metodologia e Pré-História da África (ed. Jospeh Ki-Zerbo). Brasília: UNESCO, 2010 .

HOUNTONDJI, Paulin. Conhecimento de África, conhecimento de africanos: duas perspectivas sobre os estudos africanos. In: Revista Crítica de Ciências Sociais, São Paulo, n. 80, 2008.

KI-ZERBO, Joseph. Introdução geral. In: História geral da África, I: Metodologia e Pré-História da África. Brasília: UNESCO, 2010

LOPES, José de Sousa Miguel. Cultura acústica e cultura letrada: o sinuoso percurso da literatura em Moçambique. In: LEÃO, Ângela Vaz (Org.). Contatos e ressonâncias: literaturas africanas de língua portuguesa. Belo Horizonte: PUC Minas, 2003.

MALOA, Joaquim Miranda. O lugar do marxismo em Moçambique. Revista Espaço Acadêmico, Maringá, n. 122, jul. 2011.

MONDLANE, Eduardo. A estrutura social - mitos e fatos e Resistência - a procura de um movimento nacional. Trechos de Lutar por Moçambique (1995). In: SANCHES, Manuela Ribeiro (Org.). As malhas que os impérios tecem. Lisboa: Edições 70, 2011.

NAPOLITANO, Marcos. Arte e Revolução: entre o artesanato dos sonhos e a engenharia das almas (1917 - 1968). In: Revista de Sociologia e Política, Curitiba, n. 8, 1997.

Submetido em: 01 de julho de 2015. Aceito para publicação em: 13 de outubro de 2015. 
